\title{
The Importance of Properly Assessing Social, Environmental and Political Risks in Foreign Direct Investment in Chinese IT Industry
}

\author{
H. Liu
}

\begin{abstract}
China has grabbed the attention from the world after the GFC as it has nearly not influenced by the GFC in 2008. With the high growth rate of GDP and shifting from labor-intensive production to capital intensive production, Chinese IT market has been seen as a rising new market. There are massive investments has been injected the Chinese IT market. This essay analysis the environment and political risks in Chinese IT market with some examples in recent years, in order to have a clear visual angle on investment in China, helps the investors and academic researchers in the world.
\end{abstract}

Index Terms-Globalization; Business and government relation; Invest in China; Investment risks

\section{INTRODUCTION}

As globalization has been sharply processing since World War II, it leads to the role of multinational enterprises (MNEs) has been increasing in both business and politic ways. With the development of MNEs, the foreign direct investment (FDI) risks have been exposed as well. This essay is going to argue the importance of assessing and the roles of government institutions, social culture, market environment and sense of environment protections in FDI, because they can result in different risks to MNEs. To prove the argument, this essay contains five sections with examples of FDI and market situation in Chinese IT industry. Firstly this paper would briefly explain the IT industry and show the pattern of IT industry in China. Then explaining the importance of government institutions in FDI, and how government affects MNEs by using three different functions and bringing political risks. After that, this essay shows how culture elements work as a dual role in FDI and may bring culture risks to MNEs. This paper explains the market environment's influence on FDI and market environment risks could be faced by MNEs in a foreign market. At last, it points out the necessity of a sense of environment protection and it may create environment risks for MNEs by not properly protecting environment in a foreign country.

\section{IT IN CHINA}

The IT industry is a burgeoning industry in China. Davenport and Short (2003, p.98) simply define IT as the capabilities of analyzing and designing of work processes and flows offered by computers, software and telecommunication technologies. The IT development in

Manuscript received April 16, 2011.

H. Liu is working as accountant-general in Chengdu Xieli Advertising \& Designing Co., Ltd. in Sichuan, China.
China is mainly funded by government, and the overall industry is still very weak, compare to other countries. As the low development of intellectual property law, Chinese market is corroded by illegal copies. Local IT industries hardly make money in the market. IT companies' profits are mainly come from the government purchase. Chinese government is crucial in IT industry in China.

\section{POLITICAL Risks}

Political risks are mainly arisen from government and political institutions. Government as an entity plays an important role in market, which can directly and indirectly affect FDI by providing protections to domestic companies, preventing foreign companies or create opportunities for foreign companies. Globe man and Shapiro (2002, p.1901) claims that political, institutional and legal environment as an integer can be seen as governance infrastructure, and FDI inflows and outflows are highly controlled by it. The role of government in China is essential to FDI. Chinese government centralizes the power, legal system and money system. Without government allowance, firms cannot pull into China or survive from Chinese market. Google China is an example, which just pulled out of China as no valuable internet license, which leads to Google's share price have fallen 27 percent this year (Womack and Lee, 2010). It is widely believed that government has three main functions in market, which are providing protection for weak industry, preventing or limiting foreign investment stealing the market, and helping international companies bring technology into the country.

One of the political risks is government using protection functions to create unfair competitions. Lall(2003, p.2) argues that as globalization developing, government use protection function more frequently in order to balance the import and export. The protection can indirectly influence FDI by government purchasing the local products; create tax vacations for local industry or limiting MNEs' activities by licensing or special tax on particular activities. For example, China has a "Compendium for reviving the software industry" policy, which points out that government must buy the China-made software when it has the same function and quality with the foreign made software (People's Daily online, 2004, para.5). This would decrease the demand for foreign software, and drive the price of software market down as local makers have more money and easier to gather resources, then the MNEs risk losing market share and low profits.

Besides providing protections, political risks can be shown as government directly "attacking" those MNEs using legal power or taxes. Foreign companies are under the 
risk of being limited on their activities, coercively changed in the companies' ownership, charged for extra taxes or limited to transfer profit outflow of the foreign country. There is a belief that government stop acting this function but attracting FDI because of free trade agreement lead by globalization. However Hub (1996, p.223) believes that government intervention has been increasing since globalization. A good example would be Mickey Mouse in China. Mickey Mouse TV cartoon were forced call off in China, because of not permitted by government. The companies lost $\$ 2.6$ million by failed to bring Mickey Mouse DVDs to China.

\section{GOVERNMENT}

Governments indirectly affect FDI by providing limited opportunities for foreign companies. Young and Lan(1997, p.670) claims that, appropriate policy for FDI can bring China new technology and opportunities more than other countries though technology transferring. Chinese government can help foreign companies get into Chinese market. However the help provided by government would lead to the competitions on gathering government relations. Thus companies would be risk in potential competing with other foreign competitors. In most cases, the losers lost the entire market and money has spent on it. The good example is the competition of HD-DVD and Blu-ray of next generation of store format. It is a competition between Sony and Toshiba, and Blu-ray won the game by the new PlayStation3 in the world. However, as HD-DVD format now has the official backing of the Chinese government, HD-DVD has a 3\% market share leads in China, and decided to fight with Blu-ray again.(Hickey, 2009, para. 3).

\section{Cultural Risks}

Culture risks have a great influence on the return of FDI as well. It likes an invisible hand plays dual role which can push the foreign companies out or welcome them into the market. It is widely concerned that culture is an important component in FDI decision making, wrong culture analysis will leads to a huge loss in MNEs (Hardwar, Dietz, Beamish, 2007, p.49). As the difference of language, culture value and lifestyles, companies' cost may increase sharply through dealing these differences or companies and their products may be undervalued or overvalued. In Chinese IT industry case, the profit chain is a vicious circle because of Chinese people's wrong culture views. Both software and hardware are easily to find illegal copies from internet or Chinese black market. With the low level of development of intellectual property rights law and regulation, Chinese IT market is filled with faked or illegal copies, like NDKIA, SQNY, which are similar to famous brands and designs. Business Software Alliance (as cited in China economic review, 2009, para.7) announced that software industry had lost more than 6.6 billion dollars in Chinese market during 2008. Because of no profit can gain from Chinese market, IT industry is slowly developed by government funding, FDI normally avoids in the industry as Chinese people consider IT products are freely or cheaply can be downloaded or brought from internet and black markets.
The low development of intellectual property rights regulation leads to low investment, low productivity. With the high demand in Chinese market, this situation causes more supplies in illegal forms, which brings low profit to IT companies, then it eventually works as a vicious circle. For instance, the illegal copies of Windows 7 appeared in China only a week after the official announcement made by Microsoft, and an US research firm IDC found that, about $80 \%$ of software sold in China are illegal copies (China economic review, 2009, para.4). On the other hand, China has joined the WTO since 2001. The development of intellectual property has been increasing largely, Microsoft notices this advancement in culture and bring Windows7 into Chinese market may lead to a potential high return in the future. Thus the social culture still one of the most important sector need to be considered in FDI.

\section{ENVIRONMENTAL RISKS}

The market environment can be risky to FDI by rising the cost of adjusting to the local environment or shifting resources. Menses, Chung and Orr (2008) define the market environment is the structure, supply and demand and the performance of the market in a country. The market environment determines the way companies financing their project, competing in market and avoiding risks. The structure of market can easily affects MNEs. For instance, Chinese market is the socialist market economy. Governments funds and owns most large firms in market. These firms are long-term oriented, short-term profits is unnecessary but normally they have enough money to support their operation, and charges low prices for the markets, in order to provide public service or national development. Whereas MNEs mostly are looking for profits in short term, for the sake of paying dividends to investors. This is hardly competing with Chinese government owned companies. The supply and demand side normally shows the income and purchasing power of citizens. Companies can under the risk of hard to finance their project in a different market environment. Based on Chinese market, most companies are financed by government funds. The investing market is immature. Menses, Chung and Orr (2008, p.30) indicate that Chinese firms prefer to self-financed. They generally believe borrowing would raise risks. This causes foreign companies are hard to gather capitals from the market because of the low disclosure and lack of well-developed financial market. Menses, Chung and Orr also claim (2008, p.39) there is a very tight supply of qualified and experienced labor focus in Chinese high technology industry. This market environment risk can be seen as low productivity and lack of highly trained employees. The shortage of experienced employees leads to low performance but high cost to operate in Chinese market. Foreign companies may need to shift their experienced employees from elsewhere, which drives the cost acutely.

Environment protection has been noticed in recent years, companies may face financial penalties if they harm the environment. The environment pollution is mainly contributed by electronic waste or e-wastes in IT industry. Iles (2004) supports that in the electronic wastes is one of the major transnational problems in 21 st century as the 
industrial nations are shipping millions of obsolete computer to Asia every year. To do so, companies may involve in the risk of getting penalties. In Chinese IT industry, China has passed the "Electronic Disposal Law" in 2002 to making progress on environmental protection, which regards dumping electronic wastes into China as an illegal activity (Balkan, 2009, para.5). Without properly recycling the e-waste, subsidiaries importing e-waste into China will leads both subsidiaries and parents companies to a huge amount financial penalty. For instance, Monterey Park, a California based companies got busted trying to send e-waste to China, the penalties of this improperly manage e-waste is up to 37,500 US dollar per day(OHS, 2010, para.2) .

\section{CONCLUSION}

In conclusion, this essay confirms the importance of assessing political, social, market environment and environment protection these factors in FDI. By using the examples in recent 10 years development of IT industry to explain the role of government and government institutions within the industry and the political risks MNEs are faced with that are arisen from government or government institutions. The essay also shows a clue of how social culture affects the FDI in a dual role, using the example of culture value in Chinese IT market to shows the culture risks could bring some effect to MNEs. Beside the two points above, this paper also claims the market environment is essential for MNEs, it directly affect the return on FDI. In order to prove this idea, this paper uses examples in Chinese market environment. Without deeply assessing the market environment information, the FDI and MNEs are exposed to social culture risks. And by the developing of the sense of environmental protection, environment friendly are necessary for MNEs, otherwise they may be fined or under the environmental and political risks. In a word, government, social culture, market environment and environment are playing huge roles in FDI. Unless properly accessing those sectors in a foreign country, otherwise MNEs would face with certain risks in FDI.

\section{REFERENCES}

[1] Balkan, E. (2009, March 9). Stepping up efforts to control e-waste: China passes Electronic Disposal Law. [Press release]. Retrieved from: http://ewasteguide.info/stepping-efforts-con

[2] Bhardwaj, A., Dietz, J., \& Beamish, P. (2007). Host country cultural influences on foreign direct investment. Management international review. 12(3), 1-18.
[3] Brian, B., \& Lee, M. (2010). Google may lose China permit on government objections. Retrieved from: http://www.businessweek.com/news/2010-06-29/google-may-lose-chi na-permit-on-government-objections.html.

[4] China economic review. (2009, October 20).Fake Windows 7 gets there first.[Press release]. Retrieved from: http://www.chinaeconomicreview.com/china-eye/2009_10_20/Fake_ Windows_7_gets_there_first.html

[5] Davenport, T., \& Short, J. (2003). The new industrial engineering: information technology and business process redesign. In M. Lewis \& N. Slack (Eds), Operations management: critical perspectives on business and management (pp. 11-32). London: Routledge.

[6] Globerman, S., \& Shapiro, D. (2002). Global foreign direct investment flows: the role of government infrastructure. World development, 30(11), 1899-1919.

[7] Hickey, M. (2009, August 4). Blu-ray's new threat: CBHD- based on $H D$ DVD.[Press release]. Retrieved from: http://news.cnet.com/8301-17938_105-10303224-1.html

[8] Hu, P. (1996). "Mickey Mouse" in China: legal and cultural implications in a foreign direct investment. Boston university international law journal. 81(14), 72-91.

[9] Iles, A. (2004). Global environment politics: mapping environmental justice in technology flows: computer waste impacts in Asia. Massachusetts institute of technology press journal. 4(4), 76-107.

[10] Lall, S. (2003). Reinventing industrial strategy: the role of government policy in building industrial competitiveness. In G24 intergovernmental Group on Montary Affairs and Development conferences. (1-35). Dubai: QEH working paper series.

[11] Menzies, J., Chung, M., \& Orr, S. (2008). Doing business in China: how Australian companies make their decisions when entering the Chinese market. Burwood Victoria: Deakin business school, Faculty of Business and Law.

[12] OHS. (2010, January 22). California company busted trying to send e-waste to Chian. [Press relese]. Retrieved from: http://ohsonline.com/articles/2010/01/22/calif-co-busted-on-e-waste.a spx

[13] People's daily online. (2004, August 29). China's policy to protect its own software remains unchanged: CAS academician. p. 1.

[14] Young, S., \& Lan, P. (1997). Technology transfer to China through foreign direct investment. Regional studies, 31(7), 669-679. doi: $10.1080 / 00343409750130759$.

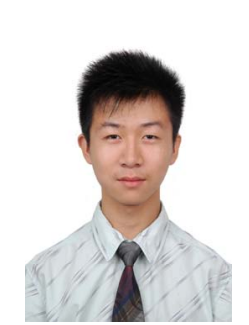

H. Liu was born in Chengdu, Sichuan Province, Southwest of China on 27th of July, 1989. He has completed a Bachelor Degree of International Business with Economic Minor at Griffith University in Brisbane, Queensland, Australia at 2011, focused on International Economic, Monetary System, Globalization and Foreign Direct Investment areas.

He has worked in Chengdu Tianyu Mechanical and Electrical Engineering Co., Ltd as accountant. Focusing on international transactions, banking advises. Now he is working as accountant-general in Chengdu Xieli Advertising \& Designing Co., Ltd. $\mathrm{He}$ has done a specific research in difference between Malaysia, China and Australia accounting standard.

Mr. Liu achieved high academic achievement at Griffith University, was invited to Honor Program. Now Mr. Liu is studying in finance at UESTC as a part-time student for his master degree. 